\title{
Clinical features of polycythaemic patients with chronic obstructive non-specific lung disease
}

\author{
J. B. COCKING and C. S. DARKE \\ Royal Infirmary and Northern General Hospital, Sheffield
}

\begin{abstract}
Forty-five patients with chronic hypoxic lung disease were studied to ascertain whether those with polycythaemia had specific distinguishing features. Thirty-three patients had red cell volumes less than $120 \%$ of the predicted normal values, and 12 patients had red cell volumes greater than this level and were regarded as polycythaemic. The latter were found to have a higher incidence of the features associated with obstructive bronchitis, whereas the nonpolycythaemic subjects had more emphysematous characteristics. These findings may facilitate the selection of those patients who may benefit from a therapeutic reduction of red cell volume.
\end{abstract}

There is evidence to suggest that patients with chronic obstructive non-specific lung disease who develop polycythaemia may have several features which differentiate them from those with normal red cell volumes. Thus they are hypoxic (Shaw and Simpson, 1961; Hume, 1968) and have been found to have a higher incidence of pulmonary hypertension, right heart failure, and hypercapnia (Baldwin, Cournand, and Richards, 1949; Harvey, Ferrer, Richards, and Cournand, 1951; Lewis, Samuels, Daines, and Hecht, 1952). Some authors have noted that polycythaemia is more likely to occur in patients with chronic obstructive bronchitis than in those with predominant emphysema (Burrows, Niden, Fletcher, and Jones, 1964; Mitchell, Vincent, Ryan, and Filley, 1964; Burrows et al., 1966) although in these latter studies the degree of polycythaemia was only assessed by measuring venous haematocrit or haemoglobin concentration. In contrast, Platts, Hammond, and Stuart-Harris (1960) found that haemoglobin concentration remained normal after the onset of cardiac failure in hypoxic and hypercapnic patients with chronic bronchitis and emphysema.

This study was undertaken to ascertain if polycythaemic patients with chronic obstructive nonspecific lung disease comprise a homogenous group which can be recognized by specific clinical features.

\section{METHODS}

CRITERIA OF PATIENT SELECTION Forty-three male and two female patients with chronic simple or mucopurulent bronchitis, as defined by the Medical Research Council Committee on the Aetiology of Chronic Bronchitis (1965), were studied. Details of patient selection have been described previously (Cocking and Darke, 1972).

FURTHER INVESTIGATIONS A questionnaire on respiratory symptoms (MRC, 1966) was completed and a full clinical examination was carried out. Posteroanterior and lateral chest radiographs were examined by an independent expert (R.G.G.), who was unaware of the patient's clinical details, and were classified as normal or showing major or minor degrees of emphysema (Laws and Heard, 1962). An electrocardiogram was assessed for right ventricular hypertrophy or right bundle-branch block (Goodwin and Abdin, 1959). Sputum was collected over three days and examined (Medical Research Council Committee on the Aetiology of Chronic Bronchitis, 1965). TLC ${ }^{1}$ and RV $^{1}$ were measured with a Godart Pulmometer and TF by the steady state method; TF measurements were also standardized for a haemoglobin concentration of $14.6 \mathrm{~g} / 100 \mathrm{ml}$ and an alveolar capillary tension of $110 \mathrm{mmHg}$ using the formula of Cotes et al. (1972) described below in the discussion. The following investigations were also performed by methods described previously (Cocking and Darke, 1972)arterial blood gases, venous haematocrit, red cell count, haemoglobin concentration, serum iron concentration and unsaturated iron binding capacity, daily dietary iron intake, alimentary blood loss, and red cell and plasma volume (expressed as a percentage of the predicted normal values). In addition blood gases were determined in 22 haematologically normal control subjects who were free of cardiorespiratory disease.

1For abbreviations see Appendix, p. 394 
STATISTICS Significance of the difference of means was determined by $t$ testing and incidence differences by the $\chi^{2}$ test.

\section{RESULTS}

Twelve patients had red cell volumes in excess of $120 \%$ predicted values and comprised the $\mathbf{P}$ group, while the remaining 33 patients were placed in the non-P group.

HISTORY AND CLINICAL FINDINGS (Tables I and II) The polycythaemic patients had several distinguishing features. They had a significantly higher incidence of previous right heart failure, $83 \%$ having been affected compared to $9 \%$ of the non-P group $(\mathbf{P}<0.001)$; furthermore, eleztrocardiographic evidence of right ventricular hypertrophy or right bundle-branch block occurred in $58 \%$ of the $\mathbf{P}$ group but in only $3 \%$ of the non$P$ group $(P<0.001)$. The radiographic findings of the two groups were also different; normal lung fields were found in $42 \%$ of the $\mathbf{P}$ group but were not observed in any non-P subject $(P<0.001)$; in contrast, major emphysema was noted in $33 \%$ of the $\mathbf{P}$ group and in $85 \%$ of the non-P group $(\mathrm{P}<0.005)$. There was also a difference in the smoking habits of the two groups, as $33 \%$ of the $\mathbf{P}$ group had never smoked compared to $3 \%$ of

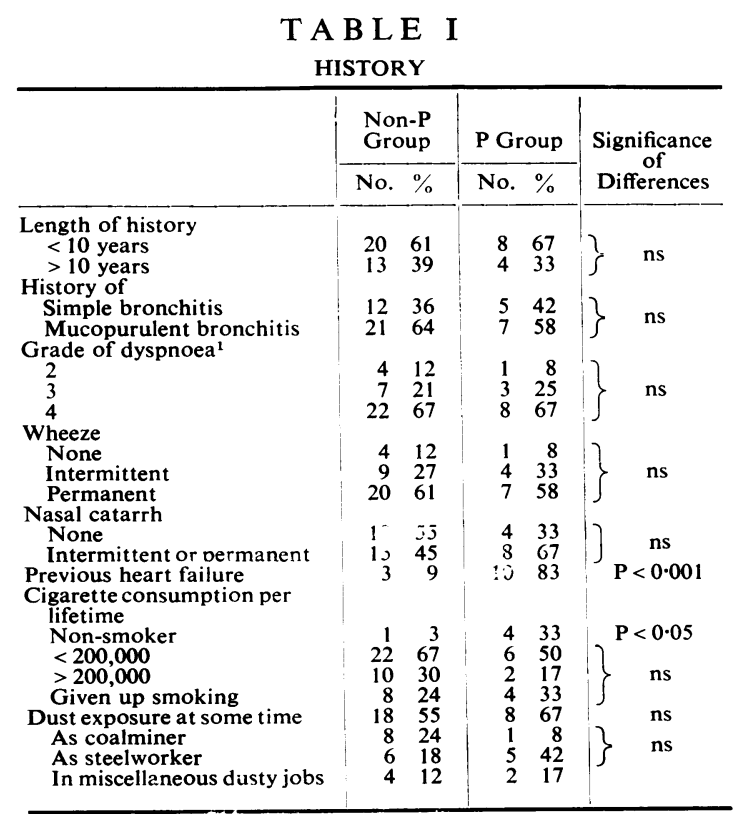

${ }_{1}$ Grade 2, breathless when hurrying on level or walking up a slight hill; 3 , breathless when walking with others of similar age on level; 4 , stops for breath on walking at own pace on level.
T A B L E I I

CLINICAL FINDINGS

\begin{tabular}{|c|c|c|c|c|c|}
\hline & \multicolumn{2}{|c|}{ Non-P Group } & \multicolumn{2}{|c|}{ P Group } & \multirow{2}{*}{$\begin{array}{l}\text { Significance } \\
\text { of } \\
\text { Differences }\end{array}$} \\
\hline & No. & $\%$ & No. & $\%$ & \\
\hline \multicolumn{6}{|l|}{ Sex } \\
\hline $\begin{array}{l}\text { Female } \\
\text { Male }\end{array}$ & \multicolumn{2}{|c|}{$\begin{array}{rr}1 & 3 \\
32 & 97\end{array}$} & \multicolumn{2}{|c|}{$\begin{array}{rr}1 & 8 \\
11 & 92\end{array}$} & \\
\hline Mean age (years) & \multicolumn{2}{|c|}{$59 \cdot 4-1.48$} & \multicolumn{2}{|c|}{$55 \cdot 7 \pm 3 \cdot 54$} & ns \\
\hline & \multirow{2}{*}{\multicolumn{2}{|c|}{$\begin{array}{l}\text { S.E.M. } \\
170 \cdot 1 \cdot 1 \cdot 45\end{array}$}} & \multirow{2}{*}{\multicolumn{2}{|c|}{$\begin{array}{l}\text { S.E.M. } \\
168 \cdot 1 \pm 2 \cdot 19\end{array}$}} & \\
\hline Mean height $(\mathrm{cm})$ & & & & & ns \\
\hline Mean weight (kg) & \multicolumn{2}{|c|}{$\begin{array}{l}\text { S.E.M. } \\
60 \cdot 9 \cdot 2 \cdot 00\end{array}$} & \multicolumn{2}{|c|}{$\begin{array}{l}\text { S.E.M. } \\
62 \cdot 2 \div 3 \cdot 62\end{array}$} & ns \\
\hline Sputum production/day & \multicolumn{2}{|c|}{ S.E.M. } & \multicolumn{2}{|c|}{ S.E.M. } & \\
\hline$<10 \mathrm{ml}$ & 25 & 76 & 6 & 50 & \\
\hline$>10 \mathrm{ml}$ & 8 & 24 & 6 & 50 & $\mathrm{~ns}$ \\
\hline \multicolumn{6}{|l|}{ Sputum purulence } \\
\hline No sputum & 1 & 3 & 0 & 0 & \\
\hline $\begin{array}{l}\mathbf{M}_{1}-\mathbf{P}_{1} \\
\mathbf{P}_{2}-\mathbf{P}_{3}\end{array}$ & $\begin{array}{l}22 \\
10\end{array}$ & $\begin{array}{l}67 \\
30\end{array}$ & $\begin{array}{l}6 \\
6\end{array}$ & $\begin{array}{l}50 \\
50\end{array}$ & ns \\
\hline Sputum mainly grew a & & & & & \\
\hline \multicolumn{6}{|l|}{ Chest radiographic } \\
\hline findings & & & & & \\
\hline $\begin{array}{l}\text { Normal (N) } \\
\text { Minor emphysema (e) }\end{array}$ & $\begin{array}{l}0 \\
5^{1}\end{array}$ & $\begin{array}{r}0 \\
15\end{array}$ & $5^{1}$ & $\begin{array}{l}42 \\
25\end{array}$ & $P<0.001$ \\
\hline $\begin{array}{l}\text { Minor emphysema (e) } \\
\text { Major emphysema (E) }\end{array}$ & 28 & 85 & $\dot{4}$ & 33 & $P<0.005$ \\
\hline \multirow{2}{*}{\multicolumn{6}{|c|}{$\begin{array}{l}\text { Grade II-IV right } \\
\text { ventricular hypertrophy } \\
\text { or right bundle-branch } \\
\text { block on ECG }\end{array}$}} \\
\hline & 1 & 3 & 7 & 58 & $P<0.001$ \\
\hline
\end{tabular}

${ }^{1}$ A patient with cardiomegaly.

the non-P group $(P<0.05)$; however, when those who had smoked at some time in their lives were considered separately, the incidence of heavy smoking, and the incidence of those who had given up the habit was similar in both groups.

The two groups did not differ in respect of length of history, severity of dyspnoea and wheeze, presence of nasal catarrh, sex incidence, and mean age, height, and weight. The incidence of those who had worked in a dusty atmosphere at some time was similar in both groups and in this category similar numbers had worked in the coal and steel industries. Although the $P$ subjects tended to produce more sputum than the non-P subjects, the incidence of those producing either more or less than $10 \mathrm{ml}$ sputum/day did not differ between the groups; nor were there differences in the incidence of those with sputum of grades $P_{2}$ and $P_{3}$ purulence or the incidence of those whose sputum cultured a dominant pathogenic organism.

RESPIRATORY FUNCTION AND BLOOD GASES (Table III) The means of $\mathrm{FEV}_{1}$ and $\mathrm{FEV}_{1} / \mathrm{FVC}^{2}$ were all severely reduced. The mean $F E_{1}$ value of $587.5 \mathrm{ml}$ found in the $\mathrm{P}$ group was significantly lower than that found in the non-P group $(727 \cdot 3$ $\mathrm{ml}$ ), but the $\mathrm{FEV}_{1} / \mathrm{FVC} \%$ means were similar. TLC and RV/TLC tended to be lower and TF tended to be higher in the polycythaemic patients although there were no significant differences between the means of the two groups. The mean standardized TF of the $\mathbf{P}$ group was signifi- 
T A B L E I I I

RESPIRATORY FUNCTION AND BLOOD GASES

\begin{tabular}{|c|c|c|c|c|c|}
\hline \multirow[b]{3}{*}{$\begin{array}{l}\mathrm{FEV}_{1}(\mathrm{ml}) \\
\mathrm{FEV}_{1} / \mathrm{FVC} \% \\
\left.\mathrm{TLC}^{2} \mathrm{ml}\right) \\
\mathrm{RV} / \mathrm{TLC} \% \\
\mathrm{TF} \text { rest } \\
(\mathrm{ml} / \mathrm{min} / \mathrm{mmHg})\end{array}$} & \multirow{2}{*}{\multicolumn{2}{|c|}{$\frac{\text { Non-P Group }}{\text { Mean } \pm \text { SEM }}$}} & \multirow{2}{*}{\multicolumn{2}{|c|}{$\frac{\text { P Group }}{\text { Mean } \pm \text { SEM }}$}} & \multirow{3}{*}{$\begin{array}{c}\begin{array}{c}\text { Signific- } \\
\text { ance of } \\
\text { Difference } \\
\text { of Means }\end{array} \\
P<0.05 \\
\text { ns } \\
\text { ns } \\
\text { ns }\end{array}$} \\
\hline & & & & & \\
\hline & $\begin{array}{r}727 \cdot 3 \\
39 \cdot 0 \\
6,082 \cdot 0 \\
60 \cdot 2\end{array}$ & $\begin{aligned} 39 \cdot 23 \\
1 \cdot 20 \\
252 \cdot 0 \\
1 \cdot 80\end{aligned}$ & $\begin{array}{r}587 \cdot 5 \\
36 \cdot 6 \\
5,183 \cdot 0 \\
57 \cdot 0\end{array}$ & $\begin{array}{c}39 \cdot 95 \\
2 \cdot 17 \\
370 \cdot 4 \\
3 \cdot 13\end{array}$ & \\
\hline $\begin{array}{l}\text { Observed } \\
\text { Standardized }\end{array}$ & $\begin{array}{l}11 \cdot 5 \\
11 \cdot 4\end{array}$ & $\begin{array}{l}0.60 \\
0.60\end{array}$ & $\begin{array}{l}14 \cdot 9 \\
13 \cdot 9\end{array}$ & $\begin{array}{l}2 \cdot 69 \\
2 \cdot 46\end{array}$ & $\begin{array}{l}\text { ns } \\
\text { ns }\end{array}$ \\
\hline $\begin{array}{l}\mathrm{SaO}_{2} \% \\
\text { Rest } \\
\text { Exercise }\end{array}$ & $\begin{array}{l}90 \cdot 7 \\
85 \cdot 1\end{array}$ & $\begin{array}{l}0.78 \\
1.46\end{array}$ & $\begin{array}{l}77 \cdot 1 \\
68 \cdot 3\end{array}$ & $\begin{array}{l}2 \cdot 40 \\
2 \cdot 49\end{array}$ & $\begin{array}{l}P<0.001 \\
P<0.001\end{array}$ \\
\hline $\begin{array}{l}\mathrm{PaO}_{2}(\mathrm{mmHg}) \\
\text { Rest } \\
\text { Exercise }\end{array}$ & $\begin{array}{l}78 \cdot 4 \\
67 \cdot 3\end{array}$ & $\begin{array}{l}1 \cdot 94 \\
2 \cdot 29\end{array}$ & $\begin{array}{l}58 \cdot 3 \\
44 \cdot 6\end{array}$ & $\begin{array}{l}5 \cdot 31 \\
5 \cdot 36\end{array}$ & $\begin{array}{l}P<0.001 \\
P<0.001\end{array}$ \\
\hline $\begin{array}{l}\mathrm{PaCO}_{2} \text { (mmHg) } \\
\text { Rest (rebreathing) } \\
\text { Rest (arterial) } \\
\text { Exercise (arterial) } \\
\text { pH }\end{array}$ & $\begin{array}{l}41 \cdot 9 \\
42 \cdot 0 \\
44 \cdot 2\end{array}$ & $\begin{array}{l}1 \cdot 51 \\
1 \cdot 27 \\
1 \cdot 62\end{array}$ & $\begin{array}{l}50 \cdot 7 \\
47 \cdot 0 \\
47 \cdot 8\end{array}$ & $\begin{array}{l}2 \cdot 52 \\
3 \cdot 09 \\
3 \cdot 52\end{array}$ & $\begin{array}{c}\mathrm{P}<0.01 \\
\text { ns } \\
\text { ns }\end{array}$ \\
\hline $\begin{array}{l}\text { Rest } \\
\text { Exercise }\end{array}$ & $\begin{array}{l}7 \cdot 36 \\
7 \cdot 34\end{array}$ & $\begin{array}{l}0.005 \\
0.005\end{array}$ & $\begin{array}{l}7 \cdot 36 \\
7 \cdot 33\end{array}$ & $\begin{array}{l}0.013 \\
0.012\end{array}$ & $\begin{array}{l}\text { ns } \\
\text { ns }\end{array}$ \\
\hline
\end{tabular}

Control results (means $\pm \mathrm{SEM}$ ): $\mathrm{SaO}_{2} 95 \cdot 8 \pm 0.44 ; \mathrm{PaO}_{2} 97 \cdot 8 \pm 2 \cdot 44$;

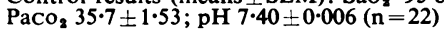

cantly lower than the mean observed TF of this group (paired $t$ test, $\mathrm{P}<0.01$ ), whereas there was no significant difference between the means of the standardized and observed TFs of the non-P group.

Although both groups were, on average, more hypoxic than the controls $(P<0.001)$, as anticipated the polycythaemic group was significantly more hypoxic than the non-P group $(\mathrm{P}<0.001)$.

Both groups were also more hypercapnic than the controls although the non-P patients had a mean that fell within the normal range. The $\mathbf{P}$ patients had a mean $\mathrm{PaCO}_{2}$ obtained by the rebreathing method that was significantly higher than that found in the non-P patients $(P<0.01)$; although the same trend was observed in the results obtained by arterial sampling, the mean values were not significantly different.

The patients were on average more acidotic than the controls $(\mathrm{P}<0.01)$, but the mean $\mathrm{pH}$ values of the two subdivisions were not significantly different.

haEmatological inVESTigations (Table IV) The mean red cell volume ( $\%$ predicted) in the non-P group was 96.4 compared to 139.3 in the $P$ group; these means are significantly different $(P<0 \cdot 001)$. There was no significant difference between the mean plasma volumes which were $92.6 \%$ predicted in the non-P group and $95.3 \%$ predicted in the $P$ group. The means of the venous haematocrits, red cell counts, and haemoglobin concentrations reflected the red cell volume findings, being
T A B L E I V

HAEMATOLOGICAL INVESTIGATIONS

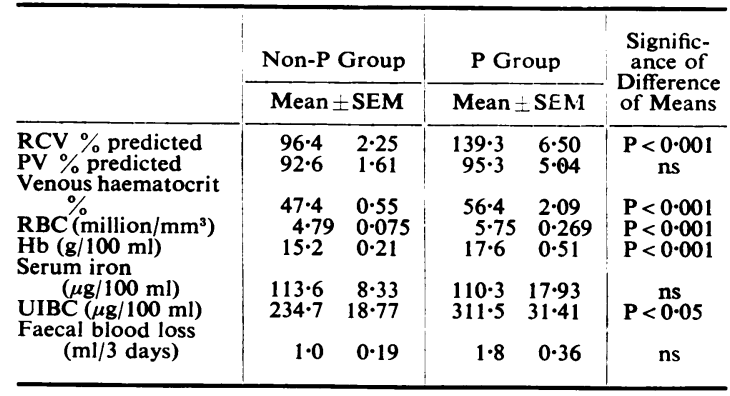

lower in the non-P patients. The two groups did not differ in respect of $\mathrm{MCV}, \mathrm{MCHC}, \mathrm{MCH}$, serum iron concentration or faecal blood loss.

Six patients $(13.4 \%)$ had iron deficiency in that they had low serum iron concentrations (mean $44.5 \mu \mathrm{g} / 100 \mathrm{ml} \pm 10.43 \mathrm{SEM})$ and total iron binding capacities (mean 438.8 $\mu \mathrm{g} / 100 \mathrm{ml} \pm 47 \cdot 11$ SEM) which were $16 \%$ saturated or less (Leading article, Lancet, 1968); however, their red cells were morphologically normal. This iron deficiency was apparently not accounted for by either inadequate dietary iron intake or excessive faecal blood loss; only one patient had a calculated daily iron intake below $12 \mathrm{mg}$, which Wintrobe (1967) considers to be the minimum daily requirement, and no patient lost more than $1.5 \mathrm{ml}$ of blood in the faeces each day (Grossman, Matsumoto, and Lichter, 1961). Iron deficiency was found in four patients in the non-P group $(12.1 \%)$ and two patients in the $P$ group $(16.7 \%)$ and therefore did not explain the difference in red cell volume in the two groups.

Seven further patients $(15.6 \%)$ had low serum iron concentrations (mean $65.9 \mu \mathrm{g} / 100 \mathrm{ml} \pm 2.44$ SEM) with well saturated total iron binding capacities (mean 266.6 \pm 27.80 SEM); none was anaemic and their red cells looked either normal or macrocytic. These findings are not indicative of iron deficiency (Verloop, Meeuwissen, and Blockhuis, 1958) but can occur in patients with chronic infection (Cartwright et al., 1946; Cartwright and Wintrobe, 1949). These features also did not account for the difference in red cell volume in the non-P and $\mathbf{P}$ patients, as their incidence was similar in the two groups, $15.2 \%$ of the non-P group and $16.7 \%$ of the P group being affected.

CORRELATIONS In the patients as a whole, red cell volume was linearly correlated with $\mathrm{SaO}_{2}(\mathrm{r}=$ $-0.681, \mathrm{P}<0.001)$ and $\mathrm{PaO}_{2}(\mathrm{r}=-0.447, \mathrm{P}<0.01)$ (Cocking and Darke, 1972). However. no signifi- 
cant relationships were demonstrable between red cell volume and hypoxia when the non-P and $P$ groups were considered separately.

\section{DISCUSSION}

In this study the subjects with polycythaemia differed from the remainder in having a higher incidence of right heart failure and right ventricular hypertrophy, more normal lung fields radiographically, more severe hypercapnia and hypoxia, and a tendency to produce more sputum, to have lower TLCs and RV/TLC ratios and higher TFs. They were therefore characterized by many of the features which Burrows and his colleagues (1964 and 1966) associated with obstructive bronchitis. In contrast, the non-polycythaemic group had a much higher incidence of emphysema with little evidence of cardiac involvement. The groups, however, were not homogeneous as some polycythaemic patients undoubtedly had predominant emphysema. The greater red cell volumes and incidence of right heart failure of the polycythaemic group can be attributed to the more severe hypoxia that occurred in these patients. There were no other factors, such as iron deficiency, gastrointestinal bleeding or chronic infection, which would explain the differences in red cell volume between the groups.

The higher TF figures which Burrows et al. (1964 and 1966) noted in their bronchitic subjects compared to those with more emphysematous features may be attributable partly to the higher haemoglobin levels which were observed in the former. Roughton and Forster (1957) showed that TF can be related to haemoglobin concentration. This has been confirmed subsequently by several workers who demonstrated that TF was relatively low in anaemia and high in polycythaemia, but reverted to more normal levels if the haemoglobin abnormality was corrected (Rankin, McNeill, and Forster, 1961; Burgess and Bishop, 1963). Cotes et al. (1972) have recently produced a simple formula by which TF can be corrected for haemoglobin concentration and this was used in the present study: TF (standardized) $=$ TF (observed) $(14 \cdot 6 \alpha+\mathrm{Hb}) \div(1+\alpha) \quad \mathrm{Hb}$ where TF (standardized) is the diffusing capacity of the lung for carbon monoxide at a haemoglobin concentration of $14.6 \mathrm{~g} / 100 \mathrm{ml}$ and an alveolar capillary oxygen tension of $110 \mathrm{mmHg}$, ' $\alpha$ ' is the $\mathrm{Dm} / \mathrm{Vc}$ ratio and $\mathrm{Hb}$ is the haemoglobin concentration in $\mathrm{g} / 100 \mathrm{ml}$. The authors found that ' $\alpha$ ' was approximately 0.7 in both anaemic and control patients, and in this study it was also assumed to apply to polycythaemic subjects, although future work may invalidate this assumption. Cotes et al. (1972) made the point that in conditions where the $\mathrm{Dm} / \mathrm{Vc}$ ratio is likely to be abnormal $\mathrm{Dm}$ and Vc should be measured separately. The effect of introducing the correction in the present study was to produce mean standardized TFs in the two groups which were closer than the mean observed TFs.

The observations made in this study may be of some practical value in the treatment of polycythaemic patients with chronic hypoxic lung disease, in whom it is sometimes the practice to reduce the red cell volume as a therapeutic measure. The justification for doing this is based on evidence which suggests that the development of polycythaemia can produce a poor prognosis in this condition (Mitchell, Webb, and Filley, 1964) due to the development of pulmonary hypertension and high blood viscosity producing heart failure and further hypoxia (Harvey et al., 1951; Renzetti, McClement, and Litt, 1966; Segel and Bishop, 1966; Dintenfass and Read, 1968; Agarwal, Paltoo, and Palmer, 1970). Furthermore, encouraging results have been obtained by those who have reduced the level of polycythaemia by, for example, using continuous oxygen (Chamberlain and Millard, 1963), venesection (Massaro and Katz, 1965; Rakita, Gillespie, and Sancetta, 1965), haemolytic drugs combined with marrow suppressants (Pengelly, 1966 and 1969), and, more recently, exchange transfusion with Dextran 40 (Harrison, Gregory, Clark, and Scott, 1971). However, the efficacies of these measures need further assessment, as all these observations were made on relatively few patients without matched controls. The selection of patients with polycythaemia for these various forms of therapy can be difficult, particularly as the venous haematocrit does not always give an indication of the size of the red cell volume, and it is obviously impractical to measure the red cell volumes of all subjects with chest disease indiscriminately. Hence the findings of this investigation may be helpful in so far as they draw attention to those patients in whom secondary polycythaemia is either likely to be present or liable to develop.

We gratefully acknowledge the help received from various departments. In particular, we thank Dr. R. G. Grainger, M.D., F.R.C.P., F.F.R., D.M.R.D., for assessing the chest radiographs, Miss E. Picton, B.Sc., Miss E. Milne, and Mrs. D. Allen, who helped with the respiratory function measurements, Miss $\mathbf{E}$. Wilson for her assistance with the radioisotope determinations, Mrs E. R. Read who took the 
dietary histories, and $\mathrm{Mr}$ A. J. Handyside, B.Sc., who advised about the statistical analyses. The manuscript was completed by Miss E. Lawton.

\section{REFERENCES}

Agarwal, J. B., Paltoo, R., and Palmer, W. H. (1970). Relative viscosity of blood at varying haematocrits in pulmonary circulation. J. appl. Physiol., 29, 866.

Baldwin, E. de F., Cournand, A., and Richards, D. W. Jr. (1949). Pulmonary insufficiency, III. A study of 122 cases of chronic pulmonary emphysema. Medicine, (Baltimore), 28, 201.

Burgess, J. H., and Bishop, J. M. (1963). Pulmonary diffusing capacity and its subdivisions in polycythaemia vera. J. clin. Invest., 42, 997.

Burrows, B., Fletcher, C. M., Heard, B. E., Jones, N. L., and Wootliffe, J. S. (1966). The emphysematous and bronchial types of chronic airways obstruction. Lancet, $1,830$.

— Niden, A. H., Fletcher, C. M., and Jones, N. L. (1964). Clinical types of chronic obstructive lung disease in London and in Chicago. Amer. Rev. resp. Dis., 90, 14.

Cartwright, G. E., Lauritsen, M. A., Jones, P. J., Merrill, I. M., and Wintrobe, M. M. (1946). The anaemia of infection. I. Hypoferremia, hyperculpremia, and alterations in porphyrin metabolism in patients. $J$. clin. Invest., 25, 65.

- and Wintrobe, M. M. (1949). Chemical, clinical, and immunological studies on the products of human plasma fractionation. XXXIX. The anaemia of infection. Studies on the iron-binding capacity of serum. J. clin. Invest., 28, 86.

Chamberlain, D. A., and Millard, F. J. C. (1963). The treatment of polycythaemia secondary to hypoxic lung disease by continuous oxygen administration. Quart. J. Med., 32, 341.

Cocking, J. B., and Darke, C. S. (1972). Blood volume studies in chronic obstructive non-specific lung disease. Thorax, 27, 44.

Cotes, J. E., Dabbs, J. M., Elwood, P. C., Hall, A. M., McDonald, A., and Saunders, M. J. (1972). Iron deficiency anaemia; its effect on transfer factor for the lung (diffusing capacity) and ventilation and cardiac frequency during submaximal exercise. Clin. Sci., 42, 325.

Dintenfass, L., and Read, J. (1968). Pathogenesis of heartfailure in acute-on-chronic respiratory failure. Lancet, $1,570$.

Goodwin, J. F., and Abdin, Z. H. (1959). The cardiogram of congenital and acquired right ventricular hypertrophy. Brit. Heart J., 21, 523.

Grossman, M. I., Matsumoto, K. K., and Lichter, R. J. (1961). Faecal blood loss produced by oral and intravenous administration of various salicylates. Gastroenterology, 40, 383.

Harrison, B. D. W., Gregory, R. J., Clark, T. J. H., and Scott, G. W. (1971). Exchange transfusion with Dextran 40 in polycythaemia secondary to hypoxic lung disease. Brit. med. J., 4, 713.

Harvey, R. M., Ferrer, M. I., Richards, D. W. Jr., and Cournand, A. (1951). Influence of chronic pulmonary disease on the heart and circulation. Amer. J. Med., $10,719$.
Hume, R. (1968). Blood volume changes in chronic bronchitis and emphysema. Brit. J. Haemat., 15, 131.

Laws, J. W., and Heard, B. E. (1962). Emphysema and the chest film: a retrospective radiological and pathological study. Brit. J. Radiol., 35, 750.

Leading article (1968). Iron deficiency without anaemia. Lancet, 1, 462.

Lewis, C. S., Samuels, A. J., Daines, M. C., and Hecht, H. H. (1952). Chronic lung disease, polycythaemia and congestive heart failure. Cardiorespiratory, vascular and renal adjustments in cor pulmonale. Circulation, 6, 874.

Massaro, D., and Katz, S. (1965). Effect of venesection on arterial gas values, and ventilatory function in patients with chronic bronchitis. Thorax, 20, 441.

Medical Research Council Committee on the Aetiology of Chronic Bronchitis (1965). Definition and classification of chronic bronchitis for clinical and epidemiological purposes. Lancet, 1, 775.

(1966). Questionnaire on Respiratory Symptoms. W. J. Holman Ltd., Dawlish, Devon.

Mitchell, R. S., Vincent, T. N., Ryan, S., and Filley, G. F. (1964). Chronic obstructive bronchopulmonary disease. IV. The clinical and physiological differentiation of chronic bronchitis and emphysema. Amer. J. med. Sci., 247, 513.

Webb, N. C., and Filley, G. F. (1964). Chronic obstructive bronchopulmonary disease. III. Factors influencing prognosis. Amer. Rev. resp. Dis., 89, 878.

Pengelly, C. D. R. (1966). Reduction of haematocrit and red-blood-cell volume in patients with polycythaemia secondary to hypoxic lung disease by dapsone and pyrimethamine. Lancet, $2,1381$.

- (1969). Reduction of excessive haematocrit levels in patients with polycythaemia due to hypoxic lung disease by phenylhydrazine hydrochloride and pyrimethamine. Postgrad. med. J., 45, 583.

Platts, M. M., Hammond, J. D. S., and Stuart-Harris, C. H. (1960). A study of cor pulmonale in patients with chronic bronchitis. Quart. J. Med., 29, 559.

Rakita, L., Gillespie, D. E., and Sancetta, S. M. (1955). The acute and chronic effects of phlebotomy on general haemodynamics and pulmonary functions of patients with secondary polycythaemia associated with pulmonary emphysema. Amer. Heart J., 70, 466.

Rankin, J., McNeill, R. S., and Forster, R. E. (1961). The effect of anaemia on the alveolar-capillary exchange of carbon monoxide in man. J. clin. Invest., 40, 1323.

Renzetti, A. D., McClement, J. H., and Litt, B. D. (1966). The Veterans Administration co-operative study of pulmonary function. III. Mortality in relation to respiratory function in chronic obstructive pulmonary disease. Amer. J. Med., 41, 115.

Roughton, F. J. W., and Forster, R. E. (1957). Relative importance of diffusion and chemical reaction rates in determining rate of exchange of gases in the human lung, with special reference to true diffusing capacity of pulmonary membrane and volume of blood in the lung capillaries. J. appl. Physiol., 11, 290.

Segel, N., and Bishop, J. M. (1966). The circulation in patients with chronic bronchitis and emphysema at rest and during exercise with special reference to the influence of changes in blood viscosity and blood volume on the pulmonary circulation. J. clin. Invest., 45, 1555. 
Shaw, D. B., and Simpson, T. (1961). Polycythaemia in TF emphysema. Quart. J. Med., 30, 135.

Verloop, M. C., Meeuwissen, J. E. T., and Blokhuis, E. W. $\mathrm{SaO}_{2}$ M. (1958). Comparison of the "iron absorption test" $\mathrm{PaO}_{2}$ with the determination of the iron-binding capacity $\mathrm{PaO}_{2}$ serum in the diagnosis of iron deficiency. Brit. J. RCV Haemat., 4, 70.

Wintrobe, M. M. (1967). Clinical Haematology, 6th ed., p. 138. Kimpton, London.

\section{APPENDIX}

\section{ABBREVIATIONS USED}

$\mathrm{FEV}_{1}$

$\mathrm{FEV}_{1} / \mathrm{FVC}$

TLC

RV
Forced expiratory volume in 1 second

Percentage of forced vital capacity expired in 1 second

Total lung capacity

Residual volume
Transfer factor (diffusing capacity) for the lung for carbon monoxide Arterial oxygen saturation Arterial oxygen tension Arterial carbon dioxide tension Red cell volume Plasma volume Red blood count Haemoglobin concentration Mean corpuscular volume Mean corpuscular haemoglobin concentration

Mean corpuscular haemoglobin Unsaturated iron binding capacity Probability

Numbers of observations

Correlation coefficient

Not significant at $5 \%$ level

Standard error of mean 